\title{
Carbonic anhydrase IX is a predictive marker of doxorubicin resistance in early-stage breast cancer independent of HER2 and TOP2A amplification
}

\section{AS Betof', ZN Rabbani' ${ }^{2}$ ME Hardee', SJ Kim ${ }^{3}$, G Broadwater ${ }^{4}$, RC Bentley', SA Snyder ${ }^{2}$, Z Vujaskovic ${ }^{2}$, E Oosterwijk ${ }^{5}$, LN Harris ${ }^{6}$, JK Horton ${ }^{2}$, MW Dewhirst ${ }^{*, 1,2}$ and KL Blackwell ${ }^{2,7}$}

'Department of Pathology, Duke University Medical Center, Room 201 MSRB, Research Drive, Box 3455 DUMC, Durham, NC, USA; ${ }^{2}$ Department of Radiation Oncology, Duke University Medical Center, Room 201 MSRB, Research Drive, Box 3455 DUMC, Durham, NC, USA; ${ }^{3}$ Department of Internal Medicine, Division of Oncology and Hematology, Korea University Medical Center, Seoul, South Korea; ${ }^{4}$ Cancer Statistical Center, Duke Cancer Institute, Box 2717 DUMC, Durham, NC, USA; ${ }^{5}$ Department of Experimental Urology, University Medical Center Nijmegen, Nijmegen, The Netherlands; ${ }^{6}$ Department of Medicine, Division of Medical Oncology, Yale University, New Haven, CT, USA; ${ }^{7}$ Department of Hematology/Oncology, Duke University Medical Center, Durham, NC, USA

BACKGROUND: In early-stage breast cancer, adjuvant chemotherapy is associated with significant systemic toxicity with only a modest survival benefit. Therefore, there is considerable interest in identifying predictive markers of response to therapy. Doxorubicin, one of the most common drugs used to treat breast cancer, is an anthracycline chemotherapeutic agent, a class of drugs known to be affected by hypoxia. Accordingly, we examined whether expression of the endogenous hypoxia marker carbonic anhydrase IX (CA IX) is predictive of outcome in early-stage breast cancer patients treated with doxorubicin.

METHODS: We obtained 209 early-stage pre-treatment surgically-resected breast tumours from patients, who received doxorubicin in their chemotherapeutic regimen and had > 10 years of follow-up. Immunohistochemistry was used to detect CA IX, and we used fluorescence in situ hybridisation to detect both human epidermal growth factor receptor (HER2) and DNA topoisomerase II-alpha (TOP2A) gene amplification.

RESULTS: Carbonic anhydrase IX intensity was significantly correlated with progression-free survival (PFS) and overall survival (OS) in patients receiving $300 \mathrm{mg} \mathrm{m}^{-2}$ of doxorubicin ( $\mathrm{HR}=1.82$ and 3.77; $P=0.0014$ and 0.010 , respectively). There was a significant, inverse correlation between CA IX score and oestrogen receptor expression, but no significant correlations were seen with either HER2 or TOP2A ratio.

CONCLUSION: We demonstrate that CA IX expression is correlated with worse PFS and OS for breast cancer patients treated with doxorubicin, independent of HER2 or TOP2A gene amplification. This study provides evidence that using CA IX to detect hypoxia in surgically-resected breast tumours may be of clinical use in choosing an appropriate chemotherapy regimen.

British Journal of Cancer (2012) 106, 916-922. doi:I0.1038/bjc.2012.32 www.bjcancer.com

Published online 14 February 2012

(C) 2012 Cancer Research UK

Keywords: breast cancer; doxorubicin; CA IX; hypoxia

Hypoxia, a pathological feature of many solid tumours, is caused by an imbalance between tumour proliferation and angiogenesis (Dang and Semenza, 1999; Dewhirst et al, 2008). Hypoxic regions are defined by an oxygen tension $\left(\mathrm{pO}_{2}\right)$ of $\leqslant 10 \mathrm{~mm} \mathrm{Hg}$. They have been identified in up to $50 \%$ of locally advanced breast tumours (Vaupel et al, 2002), and the presence of hypoxia is known to be a negative predictor of survival in cancer patients as it may contribute to more aggressive tumour phenotypes, increased invasiveness, and metastasis (Harris, 2002).

The transmembrane glycoprotein carbonic anhydrase IX (CA IX) has been identified as a potentially important marker of hypoxia in breast tumours. Known to catalyse the transformation of

*Correspondence: DrMW Dewhirst; E-mail: dewhirst@radonc.duke.edu Received I August 201 I; revised 3 January 2012; accepted 13 January 2012; published online 14 February 2012 carbon dioxide to carbonic acid, CA IX may contribute to acidification of the extracellular microenvironment in a variety of tumours (Pastorek et al, 1994; Lindskog, 1997). Expression of CA IX is dependent on the transcription factor hypoxia-inducible factor-1 (HIF-1) (Wykoff et al, 2000), and the presence or absence of CA IX is correlated with microelectrode measurements of tumour oxygenation in cervical carcinoma (Loncaster et al, 2001). Immunohistochemical studies demonstrate that CA IX co-localises with pimonidazole, a bioreductive marker of hypoxia (Olive et al, 2001). Although CA IX is widely accepted as a marker of tumour hypoxia, its prognostic significance remains the subject of significant debate (Chia et al, 2001; Bartosova et al, 2002; Span et al, 2003; Brennan et al, 2006). The differing conclusions in these studies may be explained by the fact that heterogeneous patient populations have been treated with different combinations of surgery, radiation, and chemotherapy. 
Breast cancer is the most common malignancy affecting women today aside from non-melanoma skin cancer, and it trails only lung cancer as the most common cause of cancer death in females (Jemal et al, 2008). Although standard surgical and radiotherapy techniques have resulted in over $95 \%$ local control of primary breast tumours (Bartelink et al, 2001), the 10-year overall survival (OS) rate still hovers just above $80 \%$ because of failures of local and systemic therapies (Navalta et al, 2010). Although surgery remains the mainstay of early-stage breast cancer treatment, approaches involving adjuvant chemotherapy are increasing. In early stage disease, adjuvant chemotherapy provides only a modest survival benefit while causing significant systemic toxicity and patient suffering. Thus, there is considerable interest in identifying predictive markers of response to chemotherapy to enable clinicians to select agents most likely to benefit a given patient and avoid ineffectual treatments.

Hypoxia is also widely accepted to have a role in resistance to radiotherapy and chemotherapy in a variety of human tumours. Anthracyclines, a group of chemotherapeutic agents that inhibit topoisomerase II $\alpha$, are the most common chemotherapeutic agents used worldwide to treat breast cancer. Under hypoxic conditions, cancer cells experience a large $\mathrm{pH}$ gradient across the cellular membrane, maintaining acidic extracellular and basic intracellular environments (Svastova et al, 2004). The acidic extracellular environment can decrease the uptake of anthracyclines by cells, because these drugs are weak bases, which ionise at low $\mathrm{pH}$ (Gerweck and Seetharaman, 1996). Furthermore, one of the mechanisms by which anthracyclines mediate cellular death is through iron-mediated generation of reactive oxygen species (ROS). As ROS formation is dependent on the presence of oxygen within the tumour microenvironment, anthracyclines may be less effective in hypoxic tumours. To address this potential disparity in therapeutic effectiveness, we gathered a set of early-stage breast cancer biopsies from patients who received anthracycline-based chemotherapeutic regimens and had $>10$ years of follow-up. Using immunohistochemical detection of CA IX, we demonstrate that tumour hypoxia is correlated with worse outcome for earlystage breast cancer patients treated with doxorubicin. Further, we found CA IX to predict outcome, independent of human epidermal growth factor receptor 2 (HER2) and DNA topoisomerase II-alpha (TOP2A) gene amplification.

\section{MATERIALS AND METHODS}

\section{Study population}

Breast cancer tissue samples were obtained from 209 patients from the breast cancer tissue bank of the Specialized Program of Research Excellence (SPORE) at Duke University Medical Center, Durham, NC, USA. Patient records were assessed, and 500 patients were identified who had received doxorubicincontaining chemotherapy and had a minimum of 9 years of follow-up. Of these, 209 samples had adequate tissue for analysis and had been followed $>10$ years or until tumour recurrence occurred.

Surgically excised tissues were fixed in $10 \%$ formalin, embedded in paraffin, and processed for routine histopathology. Initial histopathological evaluation was performed by a senior pathologist (RCB) and diagnosis of breast cancer was verified before processing for immunohistochemistry. Oestrogen (ER) and progesterone $(\mathrm{PR})$ receptor values were determined by ligand binding assay. Fluorescence in situ hybridisation (FISH) was used to detect amplifications in HER2 and TOP2A (Pauletti et al, 1996). Established prognostic variables were available for a majority of the tumours, including lymph nodes status, tumour size, ER status, and PR status. The clinicopathological characteristics of the entire cohort are summarised in Table 1 .
Table I Patients' clinicopathological characteristics

\begin{tabular}{|c|c|c|}
\hline Characteristics & $\begin{array}{l}\text { Number of } \\
\text { patients }\end{array}$ & $\begin{array}{l}\text { Percentage } \\
\text { (\%) }\end{array}$ \\
\hline Total patients & 209 & \\
\hline Age, (median, range) years $(n=206)$ & $48(24-79)$ & \\
\hline$<50$ & 119 & 57.8 \\
\hline$\geqslant 50$ & 87 & 42.2 \\
\hline \multicolumn{3}{|l|}{ Surgical treatment $(n=199)$} \\
\hline Lumpectomy & 8 & 4.0 \\
\hline Lumpectomy+RT & 25 & 12.6 \\
\hline Mastectomy & 120 & 60.3 \\
\hline Mastectomy+RT & 46 & 23.1 \\
\hline Tumour size, (median, range) $\mathrm{cm}(\mathrm{n}=194)$ & $3(0.3-12)$ & \\
\hline$\leqslant 2$ & 61 & 31.4 \\
\hline$>2-5$ & 105 & 54.1 \\
\hline$>5$ & 28 & 14.4 \\
\hline \multicolumn{3}{|l|}{ Node status $(\mathrm{n}=196)$} \\
\hline Negative (0) & 27 & 13.8 \\
\hline Positive $(\geqslant 1)$ & 169 & 86.2 \\
\hline \multicolumn{3}{|l|}{ ER/PR status $(\mathrm{n}=188)$} \\
\hline Both negative & 71 & 37.8 \\
\hline Either positive & 117 & 62.2 \\
\hline \multicolumn{3}{|l|}{ HER2 status $(\mathrm{n}=142)$} \\
\hline FISH ratio $<2.2$ & 114 & 80.3 \\
\hline FISH ratio $\geqslant 2.2$ & 28 & 19.7 \\
\hline \multicolumn{3}{|l|}{ TOP2A status $(\mathrm{n}=142)$} \\
\hline FISH ratio $<2.0$ & 126 & 88.7 \\
\hline FISH ratio $\geqslant 2.0$ (amplification) & 16 & 11.3 \\
\hline \multicolumn{3}{|l|}{ Adjuvant therapy $(n=201)$} \\
\hline \multicolumn{3}{|l|}{ Chemotherapy (doxorubicin) } \\
\hline $240 \mathrm{mg} \mathrm{m}^{-2}$ & 81 & 40.3 \\
\hline $300 \mathrm{mg} \mathrm{m}^{-2}$ & 120 & 59.7 \\
\hline \multicolumn{3}{|l|}{ Recurrence type $(n=206)$} \\
\hline None & 76 & 36.9 \\
\hline Local & 14 & 6.8 \\
\hline Regional & 24 & 11.7 \\
\hline Distant & 75 & 36.4 \\
\hline Other & 17 & 8.2 \\
\hline Follow-up, (median, range) years $(\mathrm{n}=193$ ) & $8.3(0.2-20.1)$ & \\
\hline No recurrence & 72 & 37.3 \\
\hline Recurrence & 89 & 46.1 \\
\hline $\begin{array}{l}\text { Death (recurrence followed by death, } \\
\text { death) }\end{array}$ & 32 & 16.6 \\
\hline
\end{tabular}

Abbreviations: $\mathrm{ER}=$ oestrogen receptor; $\mathrm{FISH}=$ fluorescence in situ hybridisation; $\mathrm{HER} 2$ = human epidermal growth factor receptor 2; PR = progesterone receptor; $\mathrm{RT}=$ radiation therapy; $\mathrm{TOP} 2 \mathrm{~A}=\mathrm{DNA}$ topoisomerase II-alpha.

\section{Treatment regimen}

All patients were treated at the Duke University Medical Center, Durham, NC, USA, and underwent either modified radical mastectomy or lumpectomy with or without breast irradiation. Two adjuvant chemotherapy regimens were used: cyclophosphamide/adriamycin (doxorubicin)/5-fluorouracil (CAF) and cyclophosphamide/adriamycin (CA). The majority of patients $(n=149,71 \%)$ received four courses of CAF (cumulative dose of doxorubicin $\left.=300 \mathrm{mg} \mathrm{m}^{-2}\right)$, whereas the other patients $(n=60$, $29 \%$ ) received four cycles of AC (cumulative dose of doxorubicin $=240 \mathrm{mg} \mathrm{m}^{-2}$ ). 


\section{Carbonic anhydrase IX Immunohistochemistry}

Immunohistochemistry for CA IX was performed with $5-\mu \mathrm{m}$ sections of formalin-fixed, paraffin-embedded tissues placed onto positively charged glass slides with a singlestaining procedure. For the detection of CA IX, we used the antiCA IX mouse monoclonal antibody clone M75 (from Dr Oosterwijk, Department of Urology, University Hospital Nijmegen, The Netherlands) (Zavada et al, 1993). Tissue sections were de-waxed and rehydrated. After quenching endogenous peroxidases with methanol and $3 \%$ hydrogen peroxide for $10 \mathrm{~min}$, microwave antigen retrieval was done twice on high power for 5 min each in citrate buffer. After blocking with $10 \%$ donkey serum for $1 \mathrm{~h}$, the slides were incubated with primary antibody $\left(3 \mu \mathrm{g} \mathrm{ml}^{-1}\right)$ overnight at $4{ }^{\circ} \mathrm{C}$ and washed with Tris-buffered saline (TBS) (Pastorekova et al, 1992). A positive control was human non-small cell carcinoma tissue, which has previously been established as positive for CA IX (Kim et al, 2004, 2005). Simultaneous incubation of slides in which primary antibody was omitted served as a negative control. Biotinylated donkey antimouse antibody $(1: 1000, \mathrm{v} / \mathrm{v})$ (Jackson ImmunoResearch Laboratories, Inc., West Grove, PA, USA) was applied for $30 \mathrm{~min}$ at room temperature, followed by application of avidin-biotin-peroxidase complex per the manufacturer's protocol (Vectastain ABC Kit, Vector Laboratories, Inc., Burlingame, CA, USA). Slides were again washed in TBS and colour was developed by a 5 min incubation in $3,3^{\prime}$-diaminobenzidine solution. Slides were counterstained with haematoxylin and mounted.

\section{Assessment of CA IX expression}

The staining was performed by two investigators (ZNR and $\mathrm{MEH}$ ) and slides were evaluated by a single board certified surgical pathologist with expertise in breast pathology (RCB), who was blinded to clinical outcome. Semi-quantitative interpretations of immunohistochemistry were performed as described (Chia et al, 2001). In brief, a score of 0-3 for the intensity of staining in the majority of the entire section with invasive carcinoma was given (CA IX intensity: $0=$ no staining; 1 = weak; 2 =moderate; 3 = strong). All slides were evaluated by light microscopy and the percentage of tumour cells throughout the section that were stained positively was estimated (\% of CA IX). The product of the intensity staining and the percentage of tumour produced a final immunostaining score (CA IX score) of $0-300$.

\section{Statistical methods}

Summary statistics were reported for the baseline discrete as well as continuous variables. Spearman's correlation coefficients were used to study the pair-wise association between HER2, TOP2A, ER expression, and PR expression, separately with CA IX measurements. The proportion of CA IX highly-positive samples, which were negative for ER and PR expression were compared using the Pearson's test of proportions. Overall survival was measured from the time of diagnosis to death and was censored at last follow-up if death did not occur. Progression-free survival (PFS) was measured from the time of diagnosis to recurrence or death and was censored for patients without an event at last follow-up date. Kaplan-Meier estimated survival curves were used to display the OS and PFS and by CA IX status. Curves were compared using the log-rank test. Cox proportional hazards regression models were used to determine if one or more variables, including CA IX measurements, type of treatment, patient baseline characteristics, and disease statuses, were predictive of overall OS or PFS.

\section{RESULTS}

\section{Patient characteristics}

The clinicopathological features of this cohort of 209 women with invasive breast cancer are described in detail in Table 1. The median age was 48 (range 24-79) years, the median tumour size was $3 \mathrm{~cm}$ (range $0.3-12$ ), $86 \%$ had node-positive disease, $53 \%$ were positive for ER, and $49 \%$ positive for PR. Of the 206 patients for whom recurrence data are available, 130 experienced recurrence and 76 did not. The median duration of follow-up for the entire cohort was 8.3 (range $0.2-20.1$ ) years. All patients were treated with appropriate surgical therapy and had negative surgical margins. Compared with other similar studies, this cohort had the advantage of all patients receiving anthracycline-based chemotherapy regimens; previous studies have largely considered heterogeneous patient groups where a variety of treatment modalities are employed. Furthermore, we have extensive follow-up data on these patients, and ER/PR status is predictive of clinical outcome (PFS based on ER/PR status, either positive $\mathrm{HR}=0.60, P=0.010$ ), as we would expect. As with all clinical cohorts, our data set is somewhat limited by the number of available patients. Another limitation is that two different doses of doxorubicin were administered.

\section{Predicted outcome based on HER2}

Table 2 displays the results of univariate Cox proportional hazards regression modelling for predicting PFS and OS based on FISH measurements of HER2. Univariately, mean HER2 is predictive of worse PFS ( $\mathrm{HR}=1.65, P=0.038)$, further validating our data set.

\section{Carbonic anhydrase IX intensity, \% of positive tumour cells, and score}

Carbonic anhydrase IX expression was evaluated by analysing the CA IX intensity, $\%$ of positive tumour cells, and CA IX score. Figure 1 shows examples of the CA IX staining. Cases were classified as positive if the overall CA IX score was $\geqslant 50$. Of the 207 cases analysed, $182(88 \%)$ cases were positive for CA IX expression, which is in line with previous reports (Span et al, 2003; Brennan et al, 2006). The staining pattern was characteristic of membranous and cytoplasmic localisation. The average intensity of CA IX staining was 1.44 on a scale of $0-3$. The average percentage of tumour cells positively stained with CA IX was $68 \%$ and the mean CA IX score was 94 .

\section{Association of CA IX expression with hormone receptor status}

We evaluated the relationship between hormone receptor expression and CA IX staining to lend insight to conflicting reports in the literature regarding such a connection. We found a significant

Table 2 Univariate prediction of progression-free survival and overall survival based on HER2 and TOP2A amplification

\begin{tabular}{lccccc}
\hline & \multicolumn{2}{c}{ Progression-free survival } & & \multicolumn{2}{c}{ Overall survival } \\
\cline { 2 - 3 } Variable & $\begin{array}{c}\text { Hazard } \\
\text { ratio }\end{array}$ & P-value & & $\begin{array}{c}\text { Hazard } \\
\text { ratio }\end{array}$ & P-value \\
\hline HER2 mean (continuous) & 1.03 & 0.069 & & 1.06 & 0.043 \\
HER2 mean $(<4 / \geqslant 4)$ & 1.65 & 0.038 & & 1.73 & 0.23 \\
TOP2A mean (continuous) & 1.09 & 0.011 & & 1.14 & 0.024 \\
TOP2A mean $(<4 / \geqslant 4)$ & 2.32 & 0.0027 & & 2.59 & 0.065 \\
\hline
\end{tabular}

Abbreviations: HER2 = human epidermal growth factor receptor 2; TOP2A =DNA topoisomerase II-alpha. Univariately, mean HER2 and mean TOP2A values $\geqslant 4.0$ are predictive of worse progression-free survival. 

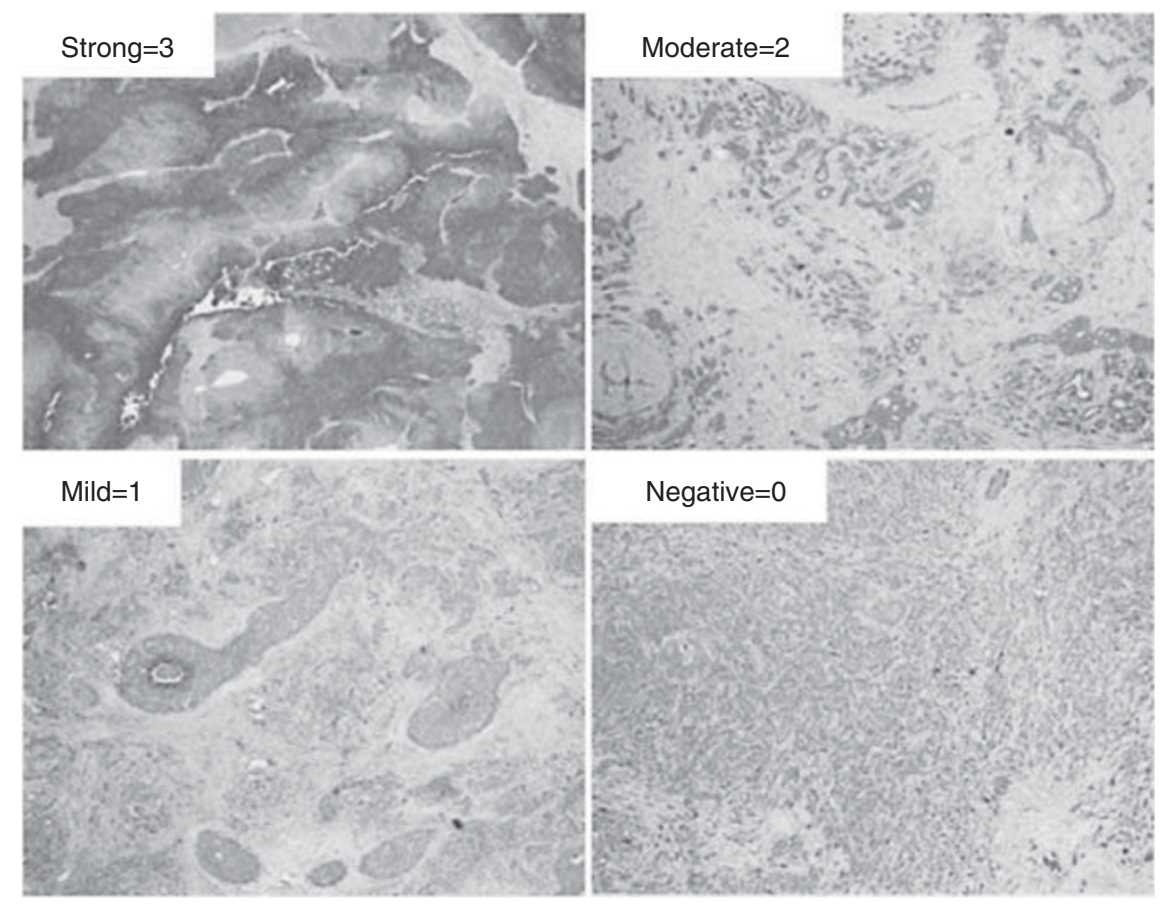

Figure I Examples of CA IX immunohistochemical staining. Carbonic anhydrase IX expression was evaluated by analysing the CA IX intensity, percent of positive tumour cells, and CA IX score. Cases were classified as positive if the overall CA IX score was greater than or equal to 50. Of the 209 cases analysed, I 82 (87\%) cases were positive for CA IX expression with both membranous and cytoplasmic localisation. The average intensity of CA IX staining was 1.44 on a scale of $0-3$. The average percentage of tumour cell positively stained with CA IX was $68 \%$ and the mean CA IX score was 94 .
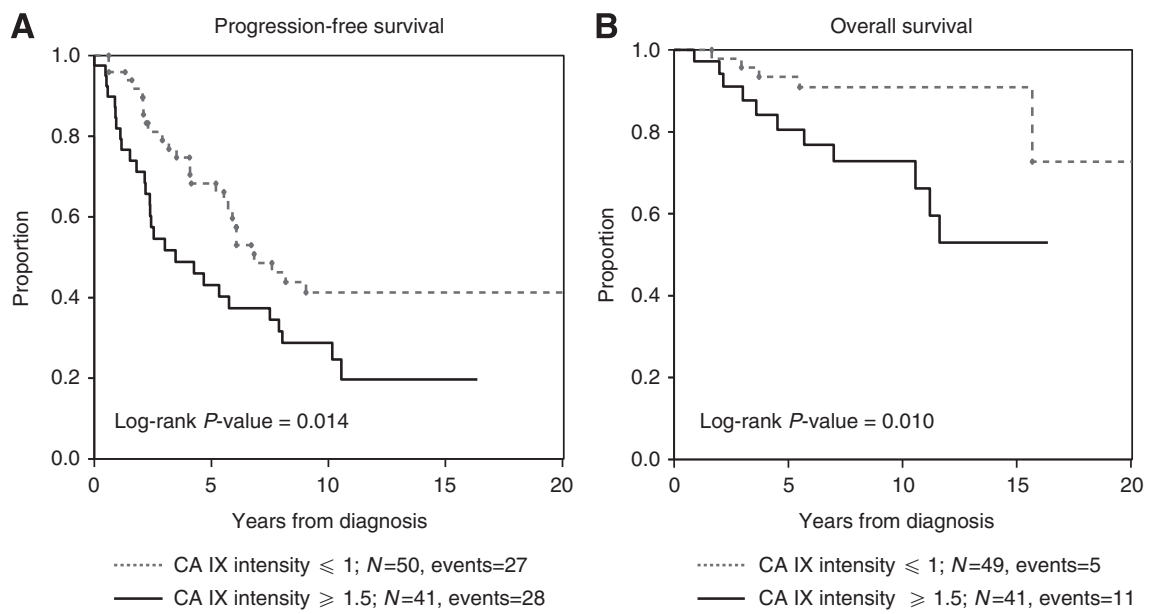

Figure 2 Kaplan-Meier survival curves for patients treated with CAF chemotherapy. Carbonic anhydrase IX staining intensity was significantly predicts (A) PFS $(P=0.014)$ and $(\mathbf{B})$ OS $(P=0.010)$.

inverse correlation between ER expression and CA IX expression $(P<0.01)$. No such correlation was observed between PR expression and CA IX $(P=0.2)$. Of note, when the samples were grouped according to staining intensity (intensity score $\leqslant 3$ ), a significantly larger proportion of the CA IX highly-positive samples were negative for ER and PR expression $(P=0.015)$.

\section{Association of CA IX expression with adjuvant therapy outcomes}

Two adjuvant chemotherapy regimens were used in this patient series: CAF and CA. The dose of doxorubicin in the CAF regimen was $300 \mathrm{mg} \mathrm{m}^{-2}$, whereas patients who received the CA regimen $(n=60)$ received $240 \mathrm{mg} \mathrm{m}^{-2}$. When patient outcomes were evaluated based on the adjuvant chemotherapy regimen, CA IX intensity significantly predicted PFS and OS in the patients treated with CAF chemotherapy (HR $=1.82$ and $3.77 ; P=0.014$ and 0.010 , $n=91$ and 90, respectively). The Kaplan-Meier analyses revealing differential PFS and OS in the CAF group are shown in Figure 2. At the lower dose of doxorubicin, no significant relationship between CA IX intensity and PFS was observed. In addition, both OS and PFS were significantly lower in the CAF-treated patients with ER- and PR-negative tumours than those whose tumours were positive for either or both receptor $(P<0.001)$.

\section{Carbonic anhydrase IX score is independent of HER2 and TOP2A amplification}

We calculated Spearman's correlation coefficients to determine the association of CA IX score with known predictive indicators such 

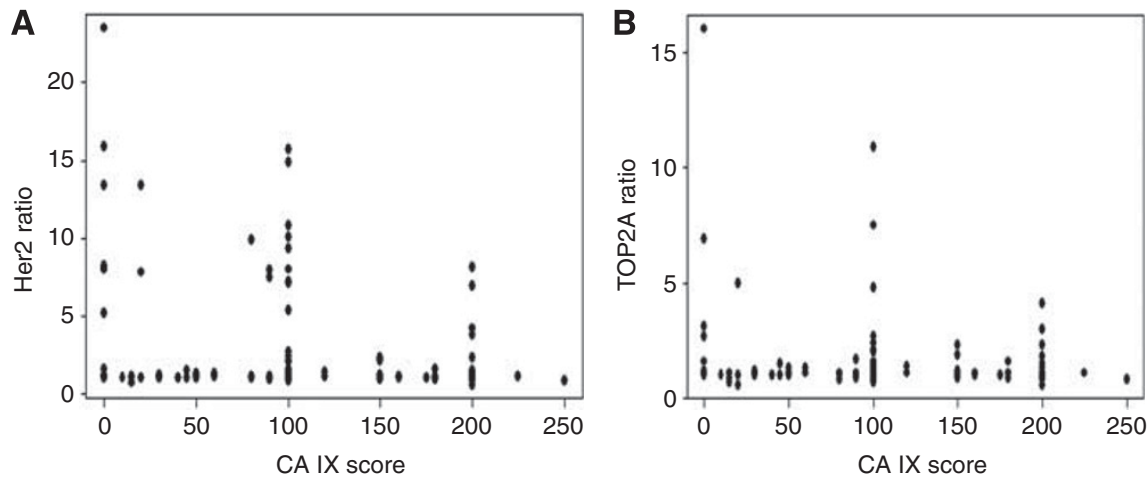

Figure 3 We calculated Spearman's correlation coefficients to determine the association of CA IX score with known predictive indicators such as HER2 and TOP2A amplification. Using FISH to detect both HER2 and TOP2A, we calculated the HER2 ratio and TOP2A ratio (number of genes of interest/ number of chromosome 17) to identify gene amplification. Here we show the relationship between the CA IX score and HER2 ratio (A) and TOP2A ratio (B), There is no significant relationship between CA IX score and either HER2 or TOP2A ratio $(n=140$; Rho $=-0.031$ and $0.023, P=0.72$ and 0.78 , respectively).

as HER2 and TOP2A gene amplification. Using FISH to detect both HER 2 and TOP2A, we calculated the HER2 ratio and TOP2A ratio (number of genes of interest/number of chromosome 17) to identify gene amplification in our samples. Figure 3 shows scatter plots of the relationship between CA IX score and these two predictive variables. No significant correlation is seen between CA IX score and either HER2 ratio or TOP2A ratio $(n=140)$. Thus, CA IX is a predictive marker of outcome in early-stage breast cancer patients treated with doxorubicin independent of HER2 and TOP2A amplification.

\section{DISCUSSION}

Doxorubicin is one of the most active chemotherapeutic agents for the treatment of advanced breast cancer (Honig, 1996; Lindley, 1997; Ranson et al, 1997; Winer et al, 2001). However, not all patients benefit from doxorubicin and its anti-tumour benefits are counterbalanced by significant toxicities (Hurny et al, 1996; Doyle et al, 2005; Hershman et al, 2007; Pinder et al, 2007). The most noteworthy doxorubicin toxicity is cardiomyopathy, but this agent is also associated with haematological toxicity, secondary leukaemia, and hepatic impairment (2010). Given the high rate of resistance to doxorubicin, coupled with the severe toxicities associated with its use, the choice of whether or not to use this effective anti-tumour agent in a particular patient is challenging. Accordingly, a predictive indicator of response to doxorubicin would be a valuable tool for clinical decision making.

Our results indicate that the endogenous hypoxia marker CA IX could be used to predict doxorubicin treatment efficacy; high expression of CA IX is correlated with worse outcomes in patients treated with CAF chemotherapy. Carbonic anhydrase IX has received considerable attention as a marker of hypoxia and indicator of patient prognosis. Previous studies report that high expression of CA IX is correlated with worse outcomes in a variety of cancers, including breast cancer (Koukourakis et al, 2001; Loncaster et al, 2001; Hui et al, 2002; Swinson et al, 2003; Bui et al, 2004; Hussain et al, 2004). Furthermore, expression of CA IX has been shown to predict disease-free survival and response to epirubicin in hormone-responsive breast cancer patients treated with neoadjuvant epirubicin followed by adjuvant cyclophosphamide, methotrexate, and 5-fluorouracil (Generali et al, 2006). Epirubicin is a doxorubicin analogue that functions by similar mechanisms, so we hypothesised that CA IX would also be predictive of response to doxorubicin. Indeed, this study is the first to show that expression of CA IX is predictive of CAF chemotherapeutic effectiveness, suggesting that patients whose tumours strongly express CA IX should be treated with a non-anthracycline containing chemotherapeutic regimen. Doing so could spare these patients from a likely ineffective treatment with a highly toxic agent.

This stratification approach to treatment selection may be particularly effective for patients with more aggressive cancer subtypes. Patients with ER negative tumours have significantly worse outcomes regardless of tumour stage, so appropriate and tailored chemotherapeutic selection is especially critical in this population (Ries and Eisner, 2007). As in other reports, CA IX expression in our series correlated significantly with negative ER status (Tan et al, 2009). This key steroid receptor may, in fact, be downregulated by hypoxia (Cooper et al, 2004). Furthermore, beyond transcriptional repression of ER, proliferation could be driving high levels of oxygen consumption leading to hypoxia. The oxygen consumption rate of proliferating cells is three to five times higher than quiescent cells (Freyer et al, 1984). Accordingly, it has been shown that oxygen consumption rate is five to thirty times more influential in causing hypoxia than alterations in perfusion or vascular oxygen concentration (Secomb et al, 1995). As most highly proliferative cells do not express ER, oxygen consumption could explain the negative relationship between expression of CA IX and ER (Jensen et al, 2001). In this high-risk patient population, evidence-guided selection of chemotherapeutic agents alongside of strategies to inhibit cell signalling pathways activated by hypoxia might improve treatment efficacy and disease outcomes.

In this series, both radiation and 5-FU are potential confounding factors because of differences in treatment regimens. However, similar proportions of patients with high- and low-CA IX staining intensity received radiation therapy $(P=0.19)$, so radiation therapy is unlikely to explain the differences in PFS and OS that correlate with differential expression of CA IX. It has been reported that hypoxia can reduce the cytotoxicity of 5-FU (Grau and Overgaard, 1992). This may occur by the initiation of cell-cycle arrest and/or by inhibiting activation of p53 signalling pathways (Achison and Hupp, 2003; Yoshiba et al, 2009). Thus, we cannot rule out that differences in outcome for the group of patients treated with CAF could have been influenced by the addition of 5 -FU to the treatment regimen.

The identification of CA IX as an important marker of doxorubicin-treatment outcome is strengthened by our finding that this marker has predictive power independent of HER2 and TOP2A gene amplification status. Several large clinical studies conducted by multiple groups indicate that anthracycline-containing regimens only incrementally benefit the $\sim 25 \%$ of breast cancer patients that have HER2 amplification or overexpression over non-anthracycline-containing regimens (Muss et al, 1994; Paik et al, 1998; Thor et al, 1998; Dressler et al, 2005; PiccartGebhart, 2006; Pritchard et al, 2006; Gennari et al, 2008). 
Furthermore, the HER2 gene is located on chromosome 17q21-22, close to TOP $2 A$, resulting in $33-60 \%$ of HER2-positive tumours containing concurrent modifications of TOP2A (Smith et al, 1993; Jarvinen et al, 2000; Bofin et al, 2003; Olsen et al, 2004). Anthracyclines, including doxorubicin, inhibit topoisomerase II $\alpha$, the protein product of TOP $2 A$, which is an essential mediator of DNA replication and RNA transcription (Withoff et al, 1996b). So, it was unsurprising when overexpression of TOP2A protein was correlated with increased sensitivity to anthracyclines (Withoff et al, 1996a, b; Jarvinen et al, 2000).

In our series, the value of CA IX as a predictive marker of response to doxorubicin appears to be independent of HER2 and/or TOP $2 A$ amplification, suggesting a novel mechanism of anthracycline treatment resistance related to tumour hypoxia. One of the key mechanisms of anthracycline cytotoxicity is the drug's ability to reduce molecular oxygen to oxygen free radicals, and its effectiveness has been shown to be diminished both in vitro and in vivo in response to reduced availability of oxygen (Davies and Doroshow, 1986; Doroshow and Davies, 1986; Teicher et al, 1990;
Frederiksen et al, 2003; Song et al, 2006). There are very few predictive markers available for sensitivity to anthracycline therapy and therapeutic interventions that could modulate hypoxia should have an important role in improving anthracycline sensitivity. Numerous strategies are currently under investigation to directly target tumour hypoxia, including the hypoxia cytotoxin tirapazamine, HIF-1 targeted agents, gene therapy, and increasing oxygenation using erythropoietin (Shannon et al, 2003). However, the success of these hypoxia targeting strategies has been limited to date. Given the high rate of breast tumour hypoxia identified in our primary breast cancer series, further investigation is warranted to explore the mechanisms underlying hypoxia-related doxorubicin resistance.

\section{ACKNOWLEDGEMENTS}

This study was supported by NIH/National Cancer Institute Grant CA40355 and the Duke SPORE for breast cancer.

\section{REFERENCES}

Health NIo (2010) Adriamycin (Doxorubicin Hydrochloride) Injection, Solution (ed). US National Library of Medicine: Bethesda, MD

Achison M, Hupp TR (2003) Hypoxia attenuates the p53 response to cellular damage. Oncogene 22(22): $3431-3440$

Bartelink H, Horiot JC, Poortmans P, Struikmans H, Van den Bogaert W, Barillot I, Fourquet A, Borger J, Jager J, Hoogenraad W, Collette L, Pierart M (2001) Recurrence rates after treatment of breast cancer with standard radiotherapy with or without additional radiation. $N$ Engl J Med 345(19): $1378-1387$

Bartosova M, Parkkila S, Pohlodek K, Karttunen TJ, Galbavy S, Mucha V, Harris AL, Pastorek J, Pastorekova S (2002) Expression of carbonic anhydrase IX in breast is associated with malignant tissues and is related to overexpression of c-erbB2. J Pathol 197(3): 314-321

Bofin AM, Ytterhus B, Hagmar BM (2003) TOP2A and HER-2 gene amplification in fine needle aspirates from breast carcinomas. Cytopathology 14(6): $314-319$

Brennan DJ, Jirstrom K, Kronblad A, Millikan RC, Landberg G, Duffy MJ, Ryden L, Gallagher WM, O'Brien SL (2006) CA IX is an independent prognostic marker in premenopausal breast cancer patients with one to three positive lymph nodes and a putative marker of radiation resistance. Clin Cancer Res 12(21): 6421-6431

Bui MH, Visapaa H, Seligson D, Kim H, Han KR, Huang Y, Horvath S, Stanbridge EJ, Palotie A, Figlin RA, Belldegrun AS (2004) Prognostic value of carbonic anhydrase IX and KI67 as predictors of survival for renal clear cell carcinoma. J Urol 171(6 Pt 1): 2461-2466

Chia SK, Wykoff CC, Watson PH, Han C, Leek RD, Pastorek J, Gatter KC, Ratcliffe P, Harris AL (2001) Prognostic significance of a novel hypoxiaregulated marker, carbonic anhydrase IX, in invasive breast carcinoma. J Clin Oncol 19(16): $3660-3668$

Cooper C, Liu GY, Niu YL, Santos S, Murphy LC, Watson PH (2004) Intermittent hypoxia induces proteasome-dependent down-regulation of estrogen receptor alpha in human breast carcinoma. Clin Cancer Res 10(24): $8720-8727$

Dang CV, Semenza GL (1999) Oncogenic alterations of metabolism. Trends Biochem Sci 24(2): $68-72$

Davies KJ, Doroshow JH (1986) Redox cycling of anthracyclines by cardiac mitochondria. I. Anthracycline radical formation by NADH dehydrogenase. J Biol Chem 261(7): 3060-3067

Dewhirst MW, Cao Y, Moeller B (2008) Cycling hypoxia and free radicals regulate angiogenesis and radiotherapy response. Nat Rev Cancer 8(6): 425-437

Doroshow JH, Davies KJ (1986) Redox cycling of anthracyclines by cardiac mitochondria. II. Formation of superoxide anion, hydrogen peroxide, and hydroxyl radical. J Biol Chem 261(7): 3068-3074

Doyle JJ, Neugut AI, Jacobson JS, Grann VR, Hershman DL (2005) Chemotherapy and cardiotoxicity in older breast cancer patients: a population-based study. J Clin Oncol 23(34): 8597-8605

Dressler LG, Berry DA, Broadwater G, Cowan D, Cox K, Griffin S, Miller A, Tse J, Novotny D, Persons DL, Barcos M, Henderson IC, Liu ET, Thor A,
Budman D, Muss H, Norton L, Hayes DF (2005) Comparison of HER2 status by fluorescence in situ hybridization and immunohistochemistry to predict benefit from dose escalation of adjuvant doxorubicin-based therapy in node-positive breast cancer patients. J Clin Oncol 23(19): 4287-4297

Frederiksen LJ, Siemens DR, Heaton JP, Maxwell LR, Adams MA, Graham $\mathrm{CH}$ (2003) Hypoxia induced resistance to doxorubicin in prostate cancer cells is inhibited by low concentrations of glyceryl trinitrate. J Urol 170(3): $1003-1007$

Freyer JP, Tustanoff E, Franko AJ, Sutherland RM (1984) In situ oxygen consumption rates of cells in V-79 multicellular spheroids during growth. J Cell Physiol 118(1): 53-61

Generali D, Fox SB, Berruti A, Brizzi MP, Campo L, Bonardi S, Wigfield SM, Bruzzi P, Bersiga A, Allevi G, Milani M, Aguggini S, Dogliotti L, Bottini A, Harris AL (2006) Role of carbonic anhydrase IX expression in prediction of the efficacy and outcome of primary epirubicin/tamoxifen therapy for breast cancer. Endocr Relat Cancer 13(3): 921-930

Gennari A, Sormani MP, Pronzato P, Puntoni M, Colozza M, Pfeffer U, Bruzzi P (2008) HER2 status and efficacy of adjuvant anthracyclines in early breast cancer: a pooled analysis of randomized trials. J Natl Cancer Inst 100(1): $14-20$

Gerweck LE, Seetharaman K (1996) Cellular pH gradient in tumor versus normal tissue: potential exploitation for the treatment of cancer. Cancer Res 56(6): 1194-1198

Grau C, Overgaard J (1992) Effect of etoposide, carmustine, vincristine, 5fluorouracil, or methotrexate on radiobiologically oxic and hypoxic cells in a $\mathrm{C} 3 \mathrm{H}$ mouse mammary carcinoma in situ. Cancer Chemother Pharmacol 30(4): $277-280$

Harris AL (2002) Hypoxia-a key regulatory factor in tumour growth. Nat Rev Cancer 2(1): $38-47$

Hershman D, Neugut AI, Jacobson JS, Wang J, Tsai WY, McBride R, Bennett CL, Grann VR (2007) Acute myeloid leukemia or myelodysplastic syndrome following use of granulocyte colony-stimulating factors during breast cancer adjuvant chemotherapy. J Natl Cancer Inst 99(3): 196-205

Honig S (1996) Treatment of metastatic disease: hormonal and chemotherapy. In: Diseases of the Breast, Harris J, Lippman M, Morrow M (eds). pp 669-734. Lippincott-Raven: Philadelphia

Hui EP, Chan AT, Pezzella F, Turley H, To KF, Poon TC, Zee B, Mo F, Teo PM, Huang DP, Gatter KC, Johnson PJ, Harris AL (2002) Coexpression of hypoxia-inducible factors 1alpha and 2alpha, carbonic anhydrase IX, and vascular endothelial growth factor in nasopharyngeal carcinoma and relationship to survival. Clin Cancer Res 8(8): 2595-2604

Hurny C, Bernhard J, Coates AS, Castiglione-Gertsch M, Peterson HF, Gelber RD, Forbes JF, Rudenstam CM, Simoncini E, Crivellari D, Goldhirsch A, Senn HJ (1996) Impact of adjuvant therapy on quality of life in women with node-positive operable breast cancer. Lancet 347(9011): $1279-1284$

Hussain SA, Palmer DH, Ganesan R, Hiller L, Gregory J, Murray PG, Pastorek J, Young L, James ND (2004) Carbonic anhydrase IX, a marker 
of hypoxia: correlation with clinical outcome in transitional cell carcinoma of the bladder. Oncol Rep 11(5): 1005-1010

Jarvinen TA, Tanner M, Rantanen V, Barlund M, Borg A, Grenman S, Isola J (2000) Amplification and deletion of topoisomerase IIalpha associate with ErbB-2 amplification and affect sensitivity to topoisomerase II inhibitor doxorubicin in breast cancer. Am J Pathol 156(3): 839-847

Jemal A, Siegel R, Ward E, Hao Y, Xu J, Murray T, Thun MJ (2008) Cancer statistics, 2008. CA Cancer J Clin 58(2): 71-96

Jensen EV, Cheng G, Palmieri C, Saji S, Makela S, Van Noorden S, Wahlstrom T, Warner M, Coombes RC, Gustafsson JA (2001) Estrogen receptors and proliferation markers in primary and recurrent breast cancer. Proc Natl Acad Sci USA 98(26): 15197-15202

Kim SJ, Rabbani ZN, Dewhirst MW, Vujaskovic Z, Vollmer RT, Schreiber EG, Oosterwijk E, Kelley MJ (2005) Expression of HIF-1alpha, CA IX, VEGF, and MMP-9 in surgically resected non-small cell lung cancer. Lung Cancer 49(3): 325-335

Kim SJ, Rabbani ZN, Vollmer RT, Schreiber EG, Oosterwijk E, Dewhirst MW, Vujaskovic Z, Kelley MJ (2004) Carbonic anhydrase IX in early-stage non-small cell lung cancer. Clin Cancer Res 10(23): 7925 - 7933

Koukourakis MI, Giatromanolaki A, Sivridis E, Simopoulos K, Pastorek J, Wykoff CC, Gatter KC, Harris AL (2001) Hypoxia-regulated carbonic anhydrase-9 (CA9) relates to poor vascularization and resistance of squamous cell head and neck cancer to chemoradiotherapy. Clin Cancer Res 7(11): 3399-3403

Lindley C (1997) In: Pharmacotherapy: a Pathophysiologic Approach DiPiro J, Talbert R, Yee G (eds). pp 2467 - 2497. Appleton \& Lange: Stamford, CT

Lindskog S (1997) Structure and mechanism of carbonic anhydrase. Pharmacol Ther 74(1): $1-20$

Loncaster JA, Harris AL, Davidson SE, Logue JP, Hunter RD, Wycoff CC, Pastorek J, Ratcliffe PJ, Stratford IJ, West CM (2001) Carbonic anhydrase (CA IX) expression, a potential new intrinsic marker of hypoxia: correlations with tumor oxygen measurements and prognosis in locally advanced carcinoma of the cervix. Cancer Res 61(17): 6394-6399

Muss HB, Thor AD, Berry DA, Kute T, Liu ET, Koerner F, Cirrincione CT, Budman DR, Wood WC, Barcos M, Henderson IC. (1994) c-erbB-2 expression and response to adjuvant therapy in women with nodepositive early breast cancer. $N$ Engl J Med 330(18): 1260 - 1266

Navalta JW, McFarlin BK, Lyons TS (2010) Does exercise really induce lymphocyte apoptosis? Front Biosci (Elite Ed) 2: 478-488

Olive PL, Aquino-Parsons C, MacPhail SH, Liao SY, Raleigh JA, Lerman MI, Stanbridge EJ (2001) Carbonic anhydrase 9 as an endogenous marker for hypoxic cells in cervical cancer. Cancer Res 61(24): 8924-8929

Olsen KE, Knudsen H, Rasmussen BB, Balslev E, Knoop A, Ejlertsen B, Nielsen KV, Schonau A, Overgaard J (2004) Amplification of HER2 and TOP2A and deletion of TOP2A genes in breast cancer investigated by new FISH probes. Acta Oncol 43(1): 35-42

Paik S, Bryant J, Park C, Fisher B, Tan-Chiu E, Hyams D, Fisher ER, Lippman ME, Wickerham DL, Wolmark N (1998) erbB-2 and response to doxorubicin in patients with axillary lymph node-positive, hormone receptor-negative breast cancer. J Natl Cancer Inst 90(18): 1361 - 1370

Pastorek J, Pastorekova S, Callebaut I, Mornon JP, Zelnik V, Opavsky R, Zat'ovicova M, Liao S, Portetelle D, Stanbridge EJ, Zavada J, Burny A Kettmann R (1994) Cloning and characterization of MN, a human tumorassociated protein with a domain homologous to carbonic anhydrase and a putative helix-loop-helix DNA binding segment. Oncogene 9(10): 2877-2888

Pastorekova S, Zavadova Z, Kostal M, Babusikova O, Zavada J (1992) A novel quasi-viral agent, $\mathrm{MaTu}$, is a two-component system. Virology 187(2): $620-626$

Pauletti G, Godolphin W, Press MF, Slamon DJ (1996) Detection and quantitation of HER-2/neu gene amplification in human breast cancer archival material using fluorescence in situ hybridization. Oncogene 13(1): $63-72$

Piccart-Gebhart MJ (2006) Anthracyclines and the tailoring of treatment for early breast cancer. $N$ Engl J Med 354(20): 2177-2179

Pinder MC, Duan Z, Goodwin JS, Hortobagyi GN, Giordano SH (2007) Congestive heart failure in older women treated with adjuvant anthracycline chemotherapy for breast cancer. J Clin Oncol 25(25): $3808-3815$

Pritchard KI, Shepherd LE, O’Malley FP, Andrulis IL, Tu D, Bramwell VH, Levine MN (2006) HER2 and responsiveness of breast cancer to adjuvant chemotherapy. N Engl J Med 354(20): 2103-2111
Ranson MR, Carmichael J, O’Byrne K, Stewart S, Smith D, Howell A (1997) Treatment of advanced breast cancer with sterically stabilized liposomal doxorubicin: results of a multicenter phase II trial. J Clin Oncol 15(10): $3185-3191$

Ries L, Eisner M (2007) Cancer of the Female Breast. In: SEER Survival Monograph: Cancer Survival Among Adults: U.S. SEER Program, 19882001, Patient and Tumor Characteristics, Ries L, Young J, Keel G, Eisner M, Lin Y, Horner M (eds). Chapter 13. National Cancer Institute, SEER Program: Bethesda, MD, NIH Pub. No. 07-6215

Secomb TW, Hsu R, Ong ET, Gross JF, Dewhirst MW (1995) Analysis of the effects of oxygen supply and demand on hypoxic fraction in tumors. Acta Oncol 34(3): 313-316

Shannon AM, Bouchier-Hayes DJ, Condron CM, Toomey D (2003) Tumour hypoxia, chemotherapeutic resistance and hypoxia-related therapies. Cancer Treat Rev 29(4): 297-307

Smith K, Houlbrook S, Greenall M, Carmichael J, Harris AL (1993) Topoisomerase II alpha co-amplification with erbB2 in human primary breast cancer and breast cancer cell lines: relationship to m-AMSA and mitoxantrone sensitivity. Oncogene 8(4): $933-938$

Song X, Liu X, Chi W, Liu Y, Wei L, Wang X, Yu J (2006) Hypoxia-induced resistance to cisplatin and doxorubicin in non-small cell lung cancer is inhibited by silencing of HIF-1alpha gene. Cancer Chemother Pharmacol 58(6): $776-784$

Span PN, Bussink J, Manders P, Beex LV, Sweep CG (2003) Carbonic anhydrase-9 expression levels and prognosis in human breast cancer association with treatment outcome. Br J Cancer 89(2): 271 -276

Svastova E, Hulikova A, Rafajova M, Zat'ovicova M, Gibadulinova A, Casin A, Cecchi A, Scozzafava A, Supuran CT, Pastorek J, Pastorekova S (2004) Hypoxia activates the capacity of tumor-associated carbonic anhydrase IX to acidify extracellular pH. FEBS Lett 577(3): 439-445

Swinson DE, Jones JL, Richardson D, Wykoff C, Turley H, Pastorek J, Taub N, Harris AL, O’Byrne KJ (2003) Carbonic anhydrase IX expression, a novel surrogate marker of tumor hypoxia, is associated with a poor prognosis in non-small-cell lung cancer. J Clin Oncol 21(3): 473-482

Tan EY, Yan M, Campo L, Han C, Takano E, Turley H, Candiloro I, Pezzella F, Gatter KC, Millar EK, O'Toole SA, McNeil CM, Crea P, Segara D, Sutherland RL, Harris AL, Fox SB (2009) The key hypoxia regulated gene CAIX is upregulated in basal-like breast tumours and is associated with resistance to chemotherapy. Br J Cancer 100(2): 405-411

Teicher BA, Holden SA, al-Achi A, Herman TS (1990) Classification of antineoplastic treatments by their differential toxicity toward putative oxygenated and hypoxic tumor subpopulations in vivo in the FSaIIC murine fibrosarcoma. Cancer Res 50(11): 3339-3344

Thor AD, Berry DA, Budman DR, Muss HB, Kute T, Henderson IC, Barcos M, Cirrincione C, Edgerton S, Allred C, Norton L, Liu ET (1998) erbB-2, p53, and efficacy of adjuvant therapy in lymph node-positive breast cancer. J Natl Cancer Inst 90(18): 1346-1360

Vaupel P, Briest S, Hockel M (2002) Hypoxia in breast cancer: pathogenesis, characterization and biological/therapeutic implications. Wien Med Wochenschr 152(13-14): 334-342

Winer E, Morrow M, Osborne C (2001) Malignant tumors of the breast. In: Cancer: Principles and Practice of Oncology, DeVita V, Hellman S, Rosenberg R (eds), pp 1651-1717. Lippincott Williams \& Wilkins: Philadelphia, PA

Withoff S, De Jong S, De Vries EG, Mulder NH (1996a) Human DNA topoisomerase II: biochemistry and role in chemotherapy resistance (review). Anticancer Res 16(4A): 1867-1880

Withoff S, Keith WN, Knol AJ, Coutts JC, Hoare SF, Mulder NH, de Vries EG (1996b) Selection of a subpopulation with fewer DNA topoisomerase II alpha gene copies in a doxorubicin-resistant cell line panel. Br J Cancer 74(4): $502-507$

Wykoff CC, Beasley NJ, Watson PH, Turner KJ, Pastorek J, Sibtain A, Wilson GD, Turley H, Talks KL, Maxwell PH, Pugh CW, Ratcliffe PJ, Harris AL (2000) Hypoxia-inducible expression of tumor-associated carbonic anhydrases. Cancer Res 60(24): 7075-7083

Yoshiba S, Ito D, Nagumo T, Shirota T, Hatori M, Shintani S (2009) Hypoxia induces resistance to 5 -fluorouracil in oral cancer cells via $\mathrm{G}(1)$ phase cell cycle arrest. Oral Oncol 45(2): 109-115

Zavada J, Zavadova Z, Pastorekova S, Ciampor F, Pastorek J, Zelnik V (1993) Expression of MaTu-MN protein in human tumor cultures and in clinical specimens. Int J Cancer 54(2): $268-274$

This work is published under the standard license to publish agreement. After 12 months the work will become freely available and the license terms will switch to a Creative Commons Attribution-NonCommercial-Share Alike 3.0 Unported License. 